\title{
Effect of Different Finishing and Polishing Procedures on The Discoloration of Composite Resin
}

Zeena T. Abdul Hadi Al- Ani

BDS., M.Sc

ABSTRACT: to study the effect of finishing and smoothing composite resin restoratives on discoloration of composite resin by different staining solutions .

MATERIALS AND METHODS: forty samples of tetric composite were made. These samples were divided into 4 groups. Each group was treated with a type of surface finish and immersed either in tea or coffee solution. RESULTS: The results showed that composite resin surface finished with Mylar strip and immersed in coffee was the most susceptible surface to discoloration and the least one was that immersed in tea.

CONCLUSION: composite resin surface should be finished and polished despite the smooth finish of the Mylar strip.

\section{KEYWORDS:}

surface finish, discoloration, composite resin.

CITE THIS ARTCLE:

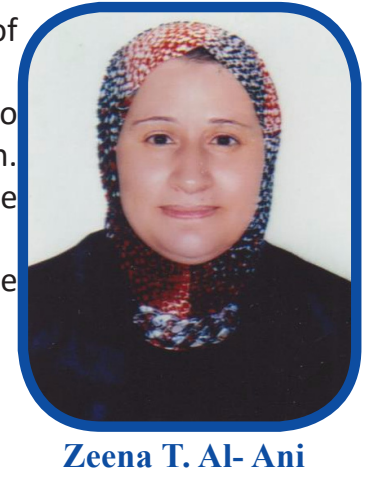

Al-Ani Z. Effect of Different Finishing and Polishing Procedures on The Discoloration of Composite Resin. Iraqi Dent. J. 2015;

37(2):73-75. http://www.iraqidentaljournal.com

\section{تاثير طرق مختلفة من التنعيم والصقل على تلون الحشوة الضوئية(كومبوست)}

ملخص البحث:لدر اسة تاثير تتعيم وصقل مادة الحشوات الضوئية على تلون هذه المادة باستعمال محاليل تلوين مختلفة.

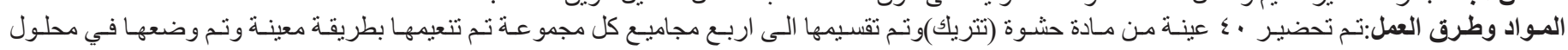

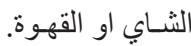

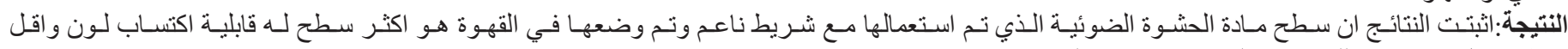

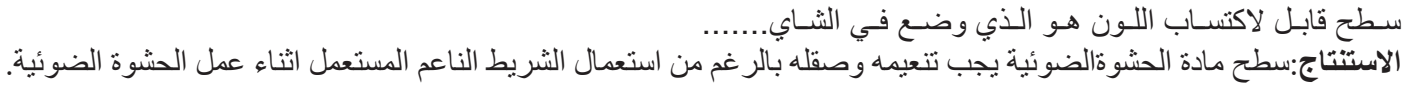

\section{INTRODUCTION}

Tooth - colored restorative materials have increasingly been used to replace missing tooth structure and to modify tooth color and contour. Therefore, the maintenance of this esthetic property may determine their useful life span. ${ }^{(1,2)}$

The surface roughness of the restoratives can also affect discoloration because a roughened surface has different surface dimensions, and different contact rates with coloring agents. ${ }^{(3,4)}$

The smoothest composite surface that is important in esthetic restorations can be obtained with a celluloid strip ${ }^{(5)}$ but there is a higher tendency of discoloration on the celluloid strip - covered composite surface, may be related to lower physical property on the surface .In order to provide color stability, wear resistance, and surface smoothness, inorganic fillers have been changed in size and shape. $(6,7)$

\section{MATRIALS AND METHODS}

Tetric composite material (vivadent Ets. FL9494 Schaan / Liechten stein) was used. A 1- mm thick celluloid mold with 2-mm height was used and a glass slide was positioned along the lower side of the mold.

A plastic instrument was used to place the composite in the mold. The numbers of specimens used were 40. Twenty of these specimens were finished with a celluloid strip and a slide glass on top of the composite and then pressed. The light -curing unit (coltolux 50, 16, Rue Louis Blanc, France) was positioned as close as possible to the slide glass and then the composite was light cured for 60 seconds, while the other twenty specimens were cured without a celluloid strip and stored in normal saline for 48 hours then finished with tungsten carbide burs (Depha carbide) to simulate finishing at a subsequent visit. Our staining solutions were coffee and tea.

Tea solution was prepared by immersing one tea bag of 1.89 gram (Fusayama) in $200 \mathrm{ml}$ of boiling water for 5 minutes then we removed the tea bag. The same weight (1.89 gram) of coffee was dissolved in $200 \mathrm{ml}$ of boiling distilled water.

Each group was subdivided into 2 groups of 10 samples and our groups were:

- Group 1=10 Samples finished with celluloid strip and immersed in tea.

- Group 2 =10 Samples finished with carbide burs and immersed in tea.

- Group 3=10 Samples finished with celluloid strip and immersed in coffee.

- Group $4=10$ Samples finished with carbide burs and immersed in coffee.

The samples were stored in the staining solutions for 7 days at $37 \mathrm{C}$ incubation.

A spectrophotometer device (TRSP - 721, Triup internat corp, V. 220v, F, 60 HZ, P. 50W) was used to measure the difference in the color of each sample in 
a wave length of 500 nanometer after measuring the control.

\section{RESULTS}

Data obtained from the colorimetric measurements are reported in Table (1) and Figure (1). Data showed that for both surface finishes, coffee produced highly significant color changes than tea.

The difference between the two values

Table (1) Descriptive statistics of the different groups

\begin{tabular}{|c|c|c|c|c|c|c|}
\hline Groups & No. & Mean & SD & SE & Min & Max \\
\hline Group 1 & 10 & 0.319 & 0.101 & 0.032 & 0.212 & 0.521 \\
\hline Group 2 & 10 & 0.082 & 0.094 & 0.029 & 0.001 & 0.242 \\
\hline Group 3 & 10 & 0.641 & 0.094 & 0.029 & 0.521 & 0.821 \\
\hline Group 4 & 10 & 0.353 & 0.071 & 0.022 & 0.212 & 0.442 \\
\hline
\end{tabular}

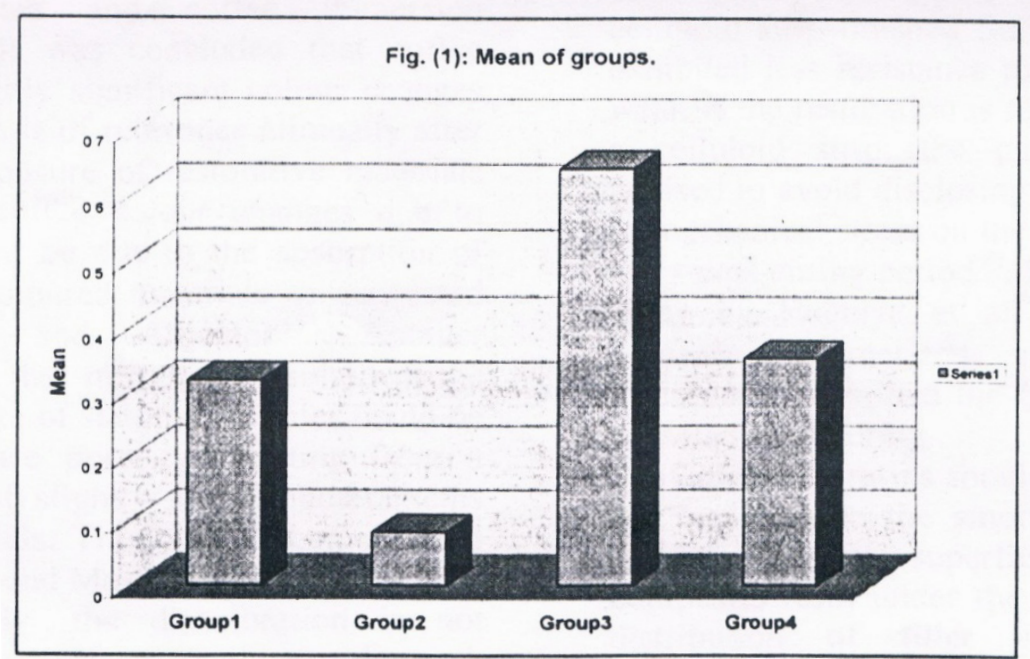

represented the amount of absorption of the solution (discoloration).

This is of relevance clinically as these changes would be apparent after extensive exposure of restorations to tea and coffee.

Tables 2 and 3 shows the statistical analysis and comparison between the groups.

Table (2): ANOVA analysis of varience test among groups

\begin{tabular}{|c|c|c|c|}
\hline Between groups & F-test & P-value & sig \\
\hline Between groups & 63.340 & 0.000 & HS \\
\hline
\end{tabular}

$* \mathbf{P}<\mathbf{0 . 0 1}$ difference $(\mathrm{HS})$

Table (3) t-test between groups

\begin{tabular}{|l|c|}
\hline \multicolumn{1}{|c|}{ Groups } & t-test \\
\hline Group 1 \& Group 2 & 5.43 \\
\hline Group 1 \& Group 3 & 7.35 \\
\hline Group 2 \& Group 4 & 7.24 \\
\hline Group 3 \& Group 4 & 7.70 \\
\hline
\end{tabular}

\begin{tabular}{|c|c|}
\hline P-value & Sig \\
\hline 0.000 & HS \\
\hline 0.000 & HS \\
0.000 & HS \\
\hline 0.000 & HS \\
\hline
\end{tabular}

*P<0.01 difference (HS)

\section{DISCUSSION}

In this study the effect of the surface finish and the immersion solutions on color changes had been studied. Table (1) and figure (1) showed the comparative staining effect of tea and coffee immersion procedures. We concluded that coffee

produced highly significant color changes than tea. This is of relevance clinically after extensive exposure of restorative materials to tea and coffee color changes due to staining which might be due to the absorption of extraneous colored materials during the long period of exposure. Coffee has a strong staining effect on composites and natural tooth structures. ${ }^{(8,9)}$. Another 
phenomenon that may have resulted in the surface uptake of staining particles could be that of surface porosity resulting from dissolution of slightly soluble components of the materials. This is in agreement with that of Gross and Moser ${ }^{(10)}$.

Apparently, the discoloration is not dependent on surface roughness alone. A strained surface is more susceptible to staining. The strain of molecular arrangement is caused by prevention of the free rearrangement of molecules of the contracting composite resin by the load of frictional confinement induced by the matrix ${ }^{(2)}$. Thus, if chemical or mechanical stress occurred in the early post curing period, the celluloid strip - finished surface would have exhibited less resistance to discoloration or wear. If the restoration is to be finished with a celluloid strip, the patient should be advised to avoid disclosing food, chemicals, or mechanical stress on the composite in the early post curing period ${ }^{(11)}$. In a discoloration study by Hachiya et al ${ }^{(12)}$ the composite surface polymerized under a matrix discolored more than the surface polished 48 hours after curing .

Composite resins should be finished and polished despite the smooth finish of the matrix strip. The superficial layer of the composite resin under the strip has a poor distribution of filler and should be removed $(13,14)$.

\section{REFERENCES}

1. Craig, R.G.: Restorative Dental materials, Mosby - year Book, Inc., 10th ed., 1997, ch. 10:244.

2. Yukimasa H. Masaaki I, Hiroyasu H., Takao F: Relation of finish to discoloration of composite resins. J. prosth Dent, 1984, 52:811-16.

3. Sarac D, Sarac YS, Kulunk T: Effects of polishing techniques on the surface roughness and color change of composite resins.J. Prosthet Dent.2006; 96:33-40.

4. Guler AU, Kurt S, KulunkT. Effects of various finishing procedures on the staining of provisional restorative materials Prosthet Dent.2005; 93:453-458.

5. Bauer JG, caputo AA: The surface of composite resin finished with instruments and matrices. J. prosth Dent, 1983, 50:351-7.

6. Yap AUJ ,Lye KW, Sau CW. Surface characteristics of toothcolored restoratives polished utilizing different polishing systems .Operative Dentistry.1997;22(6):260-265.

7. Yap AUJ, Yap SH, Teo CK, Ng JJ.: Finishing lpolishing of composite and compomer restoratives: effectiveness of one-step systems. Operative Dentistry.2004:29(3):275-279.

8. Um CM, Ruyter IE.Staining of resin-based veneering materials with coffee and tea. Quintessence Int.1991; 22:377-386.

9. Chan KC, Hormati AA, Kerber PE.Staining Calcified dental tissues with food Prosthet Dent. 1981; 46:175-178.

10. Gross MD. Moser JB. : A colorimetric study of coffee and tea staining of four composite resins J.oral Rehab. 1977, $4: 311-22$.
11. Sung Hp. IVO K, Felix L. Hardness of celluloid strip finished or polished composite surfaces with time. J. prosth. Dent., 2000, 83:660-63.

12. Helvatjo glou-Am., papadogianis YK. Koliniotou KE., Kubiass: Surface Hardness of light - cured and self cured composite resin. J. prosth. Dent .1991, 65:215-20.

13. Wilson GS.,Davies EH., Von Fraunhofer JA.:Micro hardness characteristics of anterior restorative materials. Br.Dent.J., 1980,148:37-40.

14. Hannah CM., Smith GA.: The surface finish of composite restorative materials. Br. Dent. J., 1973, 135:483-9. 